Check for updates

The BMJ

Cite this as: BMJ 2021;374:n2021 http://dx.doi.org/10.1136/bmj.n2021 Published: 13 August 2021

\section{Covid-19: Cases rise in South Korea, China, and Philippines as protests erupt in Thailand}

\author{
Elisabeth Mahase
}

Protests have broken out in Thailand, with demonstrators calling for the prime minister, Prayuth Chan-o-cha, to resign over the government's handling of the covid-19 pandemic. $^{1}$

The rally came as the country recorded new record highs, with more than 23 ooo new cases reported on 13 August and 184 deaths. ${ }^{2}$ Just $6.9 \%$ of the country's population is fully vaccinated against SARS-CoV-2.

Thailand's government is also facing criticism over new powers that would allow it to block online reports about covid-19 that may "instigate fear" even if they are true. ${ }^{3}$

Cases of covid-19 are also rising in other countries in East and South East Asia as the highly infectious delta variant spreads in the region, although the numbers are still much lower than in many European countries such as France and the UK, where new daily cases are around 30000.

\section{Record cases}

South Korea reported 2200 cases on 11 August, the highest number of new daily cases since the pandemic began. ${ }^{4}$ In response, the government has asked the public to minimise holiday travel and urged companies to allow people to work from home. The country has also just agreed a deal with Pfizer for 30 million doses of vaccine to be supplied in 2022. So far $17.4 \%$ of the country's 52 million population has had two doses. ${ }^{5}$

In China, which is following an elimination strategy with strict lockdowns, 878 cases have been reported so far in August, more than double the 390 cases reported in all of July. Concerns have also been raised over the effects of repeated lockdowns on the economy. ${ }^{6}$

In the Philippines hospitals are facing huge demand, with many reporting being near full capacity and some saying they have run out of beds in intensive care units. This comes as 13177 new cases were recorded on 13 August, bringing the country's total to 1.71 million cases, the second highest number in South East Asia after Indonesia. ${ }^{7}$ Just $11.1 \%$ of the Philippines' population is fully vaccinated.

Japan has also reported a surge in infections, with more than 18 ooo new cases on 12 August, outstripping the 15812 cases registered the previous day, according to news reports. Hospitals in Tokyo are said to be under fresh pressure, with more than 200 people reported as having serious illness, the highest number since the start of the pandemic.

The government will decide next week whether spectators will be allowed at the Paralympic Games, due to open on 24 August.

\section{Switching strategy}

In Singapore, where $67 \%$ of the population is fully vaccinated, the government has switched from an elimination to a "living with covid" strategy. The country will once again allow indoor hospitality and groups of up to five to meet if they have all had two vaccine doses. Fully vaccinated foreign workers and their dependents will also be allowed to enter the country. ${ }^{8}$

Despite the high vaccination rate, Singapore has seen several outbreaks in recent weeks. Although these forced the government to delay easing restrictions, plans are now going ahead after the number of new infections dropped below 100 a day in the week to 6 August.

Thai police face off again with protesters near PM's residence. Reuters. https://www.reuters.com/world/asia-pacific/thai-police-say-use-force-necessary-protesters-plan-new-rally-2021-08-11.

2 Record 23418 new daily Covid cases, 184 fatalities. Bangkok Post. https://www.bangkokpost.com/thailand/general/2164807/record-23-418 new-daily-covid-cases-184-fatalities.

3 As Thailand's COVID cases soar government takes critics to court. Aljazeera. https://www.aljazeera.com/news/2021/8/6/as-thailands-covid-cases-soargovernment-takes-critics-to-court.

4 South Korea's daily COVID-19 cases top 2,200, hit record. Reuters. https://www.reuters.com/world/asia-pacific/south-koreas-daily-covid-19cases-hit-record-surpassing-2200-health-minister-2021-08-10.

5 S Korea signs new Pfizer vaccine deal; asks people to cut travel. Reuters. https://www.reuters.com/world/asia-pacific/south-koreans-told-cut-holidaytravel-work-remotely-amid-rising-covid-wave-2021-08-13.

6 This map shows the latest Covid outbreak in mainland China. CNBC. https://www.cnbc.com/2021/08/13/covid-map-shows-latest-outbreak-inmainland-china-as-delta-cases-rise.html.

$7 \quad$ Philippine medical workers under strain as COVID-19 cases jump. Reuters. https://www.reuters.com/world/asia-pacific/philippines-extends-travel-ban10-countries-over-delta-concerns-2021-08-13.

8 Singapore to ease covid curbs in shift to life with virus. Bloomberg. https://www.bloomberg.com/news/articles/2021-08-06/singapore-easescovid-curbs-in-shift-to-life-with-endemic-virus?sref=VCVLK5dl.

This article is made freely available for use in accordance with BMJ's website terms and conditions for the duration of the covid-19 pandemic or until otherwise determined by BMJ. You may use, download and print the article for any lawful, non-commercial purpose (including text and data mining) provided that all copyright notices and trade marks are retained. 